\title{
OPTIMAL RENT EXTRACTION IN PRE-INDUSTRIAL ENGLAND AND FRANCE - DEFAUlT Risk AND MONITORING COSTS
}

\author{
MIKAEL PRIKS \\ CESIFO WORKING PAPER NO. 1464 \\ CATEGORY 1: PubliC FinANCE \\ MAY 2005
}
An electronic version of the paper may be downloaded
- from the SSRN website: WwW.SSRN.com
- from the CESifo website: www.CESifo.de




\title{
OPTIMAL RENT EXTRACTION IN PRE-INDUSTRIAL ENGLAND AND FRANCE - DEFAUlt Risk AND MONITORING COSTS
}

\begin{abstract}
Beginning in the mid-seventeenth century, England changed its system of raising revenues from tax farming, combined with the granting of monopolies, to direct collection within the government administration. Rents were then transferred from tax farmers and monopolists to the central government such that English public finances improved dramatically compared to both the old system and to its major competitor, France. We offer a theory explaining this development. In our view, a cost of tax farming is the ex-ante inefficiency due to the auction mechanism while a cost of direct collection is the ex-post monitoring cost the government incurs to prevent theft. When the monitoring cost is high the government therefore allows tax farmers to extract large rents to enhance their up-front payments. In addition, because revenues materialize late under direct collection, and since the government faces limited borrowing, a high default risk makes a system of up-front collection attractive. The results of the model are consistent with historical facts from England and France.
\end{abstract}

JEL Code: N43, H11.

\author{
Mikael Priks \\ Center for Economic Studies \\ at the University of Munich \\ Schackstr. 4 \\ 80539 Munich \\ Germany \\ Mikael.priks@lmu.de
}

This paper was written in part at Harvard University and in part at Stockholm University. I wish to thank Ted Bergstrom, Patrick O'Brien, Gregory Clark, Nicola Gennaioli, Edward Glaeser, Marko Köthenbürger, Rolf Henriksson, Sten Nyberg, Panu Poutvaara, Ilia Rainer, Jean-Laurent Rosenthal, Sheilagh Ogilvie, Andrei Shleifer, David Strömberg, Jakob Svensson, Jenny Säve-Söderbergh, Johan Söderberg, Francesco Trebbi, Thierry Verdier, Tom Weiss and seminar participants at Stockholm University, the University of Munich, and the EEA 2003 Conference in Stockholm. I also thank the members of the EEA 2003 Young Economist Award committee for their support of the paper. 


\section{INTRODUCTION}

Before the Civil War in England in 1640, English and French monarchs typically sold tax farmers the rights to tax goods, such as patents, licenses, salt, clothing, and trade ${ }^{1}$, and oligarchs the right to become monopolists ${ }^{2}$. The tax farmers and monopolists on their part used their positions to create huge fortunes [Brewer 1988, Swart 1980] ${ }^{3}$. In the period that followed the Civil War, however, the English fiscal system started to change in favor of direct ex-post collection through government officials [Brewer 1988, O'Brien 2002]. Along with this change, public finances improved significantly [Braddick 1996, Hunt and O'Brien 1999 and Ferguson 2001]. ${ }^{4}$ In the period that followed the Glorious Revolution in 1688 the tradition of collecting revenues up-front through tax farming was almost terminated; at the same time, officials' rents were reduced and the public finances improved dramatically [Lipson 1948,

\footnotetext{
${ }^{1}$ Swart [1980] gives a detailed description of the historical farming of taxes and the sale of office in England and France as well as in many other countries. See also Matthews [1958], North and Thomas [1973], Chandaman [1975], Ekelund and Tollison [1981], North [1981], Brewer [1988] and O'Brien [2002].

${ }^{2}$ Matthews [1958, p. 30], for example, describes how the sale of office worked in France: "The purchaser paid the government a lump sum, known as the finance of the office. This finance represented the capital or principal of the permanent loan which the purchaser was advancing to the treasury. In turn, the government attributed to the office certain salaries or perquisites known as gages. The gages were, in effect, the annual interest earned by the finance"

${ }^{3}$ In England in 1630, for example, the rents of the crown were around $£ 80000$ whereas monopolists earned between $£ 200000$ and 2300000 [Brewer 1988].

${ }^{4}$ Even though the farming of taxes was formally abandoned in the excise in 1673 and in the customs in 1683, up-front collection of revenues continued to be used in different forms [Swart 1980 and Brewer 1988].
} 
Hill 1970, Chandaman 1975 and Brewer 1988]. ${ }^{5}$ The development of the English system of revenue collection stands in stark contrast to the situation in France; here, not only tax farming was continuously used for rent extraction until the mid-nineteenth century [Brewer 1988 and Kiser and Kane 2001], but public finances fared poorly and tax farmers kept earning large rents [Brewer 1988 and Ekelund and Tollison 1981].

In this paper, we offer a theory explaining the developments that occurred in England during the seventeenth century, the differences with France and their consequences for the amount of rents appropriated by the government, private contractors and government officials.

We model the government's choice between tax farming and direct tax collection as a tradeoff between the ex-ante inefficiencies of tax farming and the ex-post monitoring costs of direct tax collection. While under tax farming the government cannot extract the full value of the office sold because of auction inefficiencies ${ }^{6}$, under direct tax collection the government must incur a cost to monitor officials to make sure that they do not steal tax revenues.

When monitoring costs are large, the government prefers to auction off offices and cash in up-front payments. ${ }^{7}$ The distributional consequence of such choice is that in so doing, the central authority allows contractors to earn large rents. On the other hand, if monitoring costs

\footnotetext{
${ }^{5}$ Ferguson [2001, p. 90] writes "In the 1670s, Charles II disposed of 2.7 times as much revenue as his benighted father had managed with such difficulty to collect just a half century earlier. Fifty years later, the revenues of the newly established Hanoverian regime were eight times, and in the 1770s eleven times, greater than those spent by Charles I."

${ }^{6}$ In our model, bidders have private information about their interest rate, and therefore about their value of the office, which together generates the inefficiency.

${ }^{7}$ Swart [1980], Brewer [1988] and Kiser and Kane [2001] all argue that when the costs of monitoring officials were high, monitoring was scarce and theft common.
} 
are low the government opts for direct tax collection. This allows it to enjoy larger revenues because now it is the government, not the official, to collect most of the value of the office.

The predictions of this theory are in line with historical evidence. Indeed, it is a common view among scholars [Chandaman 1978, Ekelund and Tollison 1981, Brewer 1988 and Kiser and Kane 2001] that during the seventeenth century the cost of monitoring officials in England fell much below the one prevailing in France, where the government's collection of indirect taxes was so difficult to be deemed "an administrative nightmare" [Brewer, 1988 p. 129].

This evidence supports the view that low monitoring costs induced English monarchs to switch to tax collection, which ultimately improved their finances, whereas the high monitoring costs that characterized France throughout the period led the French government to stick to tax farming to its great financial disadvantage.

Beyond ex-post monitoring, a fundamental difference between tax farming and direct tax collection is the timing of government's revenues. With tax farming the government receives an immediate up-front payment, with direct tax collection revenues materialize in a second period. It is thus likely that differences in government's access to debt finance shaped the choice of either method.

Incorporating this intertemporal element into the choice of the central authority, we find that when the government's default risk is high, since it faces limited borrowing, ex-post collection in combination with ex-ante borrowing is unattractive. As a result, the government prefers to let a contractor earn large rents to enhance his up-front payments. When instead the government's default risk is low, direct tax collection 
is chosen in combination with the issuing of debt. ${ }^{8}$

Our paper thus gives formal support to a number of studies arguing that high interest rates led to the change in the English revenue system. Brewer [1988] and Bordo and White [1991] argue that owing to higher interest rates faced by French monarchs, they could not afford to borrow and thus had a more inefficient revenue system than in England.

The divergence in the default risk of the French and English governments around the time of the Glorious Revolution makes sense of this story and suggests that default risk may have played an important role in shaping government's method of tax collection. Before the Revolution, the credit worthiness of both the English and the French monarchs was typically low and defaults on loans were common [see e.g. Ekelund and Tollison 1981, Brewer 1988, North and Weingast 1989, Bordo and White 1991 and Velde and Weir 1992]. After the Revolution, however, the English Parliament, in contrast to the French monarchs, never defaulted on their loans again [Brewer 1988] and it is a well-known fact that the credibility of the English Parliament was far higher than that of the French monarchs [see e.g. Bordo and White 1991 and Velde and Weir 1992].

Several papers also support the notion that monitoring costs affected the government's choice between tax farming and direct tax collection. Ekelund and Tollison [1981], Brewer [1988], O'Brien and Hunt [1999] and Kiser and Kane [2001] argue that high monitoring costs reduced the possibilities of using direct collection of taxes so that the rulers' only option was to grant monopolies. ${ }^{9}$

\footnotetext{
${ }^{8}$ Matthews [1958, p. 9] sums up our theory neatly: "Tax-farming offered two advantages: it relieved the king from the necessity of developing (in a direct sense) his own system of tax collection, and it satisfied an urgent need of cash."

${ }^{9}$ Our theory may also help explain the development in the German states. How-
} 
Overall, our paper contributes to this literature by revisiting its arguments within a micro-founded model where a self interested central authority chooses between tax farming and direct tax collection.

There are also several related papers based on economics modeling. Becker and Stigler [1974], and later Carmichael [1985], have emphasized that, to avoid shirking, prospective tax inspectors could be required to post bonds to the government. ${ }^{10}$ In our model, the up-front payment is not a bond but a sunk cost. Toma and Toma [1992] suggest that tax farmers, in contrast to government officials, are residual claimants, which gives them incentives to work hard but also to overdetect taxevasion since they do not take into account the utility loss this inflicts on taxpayers. Government officials on the other hand have incentives ever, since these states were heterogeneous it is beyond the scope of this paper to give a full treatment of the German case. In short, the German states, beginning with Prussia and ending with Württemberg, changed their fiscal system of up-front collection in favour of ex-post collection in the beginning of the nineteenth century [Ogilvie 1999]. Before the change, the system typically left officials, and not the central authority, rich [see e.g. Vierhaus 1999]. In line with our theory, the monitoring cost and the government default risk were reduced at the time of the change in the fiscal system. The infrastructure in the German states started to develop significantly at the end of the eighteenth century [Ogilvie 1999 and 2000]. The interest rates for state borrowing in the larger German states fell from around 5 percent to around 4 percent in the beginning of the nineteenth century [Homer 1963 and Hoffmann 1965]. A reason for this may have been that Germany was laid waste by Napoleon before the change, which certainly did not promote a low default risk. The stability that followed the Vienna Congress in 1815 might have reduced the default risk and, as a consequence, the interest rate for government borrowing.

${ }^{10}$ Dickens et al. [1989] however argue that due to liquidity constraints, moral hazard by employees who sack workers for no good reasons, legal restrictions on contracts which means that bonds cannot be easily enforced, and social constraints, this is not possible. 
to shirk. White [2004] takes the stand that, in line with the principalagent problem of share cropping [Stiglitz 1974], French tax farmers were used to absorb risk. Moreover, White [2004] argues, without providing a formal model, that the monarchs' monitoring costs and access to credit markets help to explain variations in the French fiscal system in the eighteenth century. Similar to Toma and Toma [1992] and White [2004] we argue that tax farmers are used to avoid monitoring costs, but in our model this system is unattractive due to inefficiencies in the auction mechanism. Johnson [2003] finally shows that tax farmers were used in France because they could make the investments necessary to collect taxes at a lower cost than the monarch could and because they worked as financial intermediaries. While Johnson focuses only on France, and on the reasons for a change in the French auction system, we study both how changes in monitoring costs and default risks affected the developments of the fiscal systems in England and in France as well as their distributional consequences. In contrast to Johnson, we also model the interaction between the central authority and the tax-collector with regard to monitoring and theft.

More generally, the paper relates to the incomplete contract literature, which studies whether a government should provide a service inhouse and when it should outsource the provision (see e.g. Laffont and Tirole 1993, Schmidt 1996 and Hart et al. 1997). ${ }^{11}$

\footnotetext{
${ }^{11}$ Other theories explaining the different development in England and France is e.g. North [1981] who argues that the difference between England and France was that English parliamentarians, in their capacity as businessmen, benefited from developing property rights. North and Weingast [1989] and later Finer [1997] instead argue that the English system of divided power (between the parliament, the crown and common law) was more efficient than the system of concentrated power in France. This argument, however, is inconsistent with Olson's [1993] view that a secure autocrat
} 
The outline of the paper is as follows. In Section II we present historical evidence from England and France on monitoring costs and default risk. The theoretical analysis, which takes its starting point in Shleifer and Vishny [1993], is presented in Section III. ${ }^{12}$ In Section IV, we allow for the possibility that agents, in addition to investors, may have been subject to the monarchs' inability to credibly commit to their decisions. Conclusions are offered in Section V.

\section{Historical Evidence on Monitoring Costs and Default Risk in England and France After THE Civil WaR}

It is a well known fact that the cost of monitoring officials was reduced in the seventeenth century in England to a level which was lower than the one in France [Chandaman 1978, Ekelund and Tollison 1981, Brewer 1988 and Kiser and Kane 2001].

A reason for this difference may be the "remarkable" growth of English urbanism from the mid-seventeenth century [Brewer 1988, p. 180]. ${ }^{13}$ When people work for companies in cities, commercial record-keeping within the government administration is more efficient than if people has an encompassing interest, which has a positive effect on economic performance.

${ }^{12}$ Similar to Shleifer and Vishny [1993], an agent sells government goods and he may or may not report the sale to the central authority. In our model, the central authority also uses the agent to extract rents for its own purposes through up-front versus ex-post collection. An additional difference is that we introduce the cost of monitoring the agent and the default risk.

${ }^{13}$ Between 1600 and 1750, the number of English towns with populations between 5000 and 10000 doubled, while in continental Europe the total of such towns fell [Brewer 1988]. In 1700, the percentage of people living in cities of at least 10000 habitants was 13.3 in England and Wales and 9.2 in France. In 1750, the percentage was 16.7 for England and Wales and 9.1 for France [De Vries 1984]. 
work in small-scale heterogeneous units on the countryside [Brewer 1988 and O'Brien and Hunt 1999]. ${ }^{14}$

Another reason for the difference in monitoring costs may be that the transportation infrastructure was less developed in France, in combination with the fact that the geography of the country was not favorable for tax collection [Szostak 1991, Oligvie 2000 and Kiser and Kane 2001]. Szostak [1991], for example, argues that roads and bridges as well as waterways were much better developed in England from the seventeenth century and onwards compared to France. "The first turnpikes were introduced in the seventeenth century, while in the first half of the eighteenth a network of turnpike roads was established linking virtually all towns in England [Szostak 1991, p. 60]. The situation was different in France. According to Szostak [1991, p. 61] "...it is clear that around 1700 the roads /in France/ were in a deplorable state". ${ }^{15}$ As for waterways, in contrast to France, England "paid considerable attention to improvement of waterways in the seventeenth and eighteenth centuries" [Szostak 1991, p. 56]. ${ }^{16}$

\footnotetext{
${ }^{14}$ There is a vast literature dealing with why England became more urban than France. One distinct difference between England and France was the English Acts of Enclosement, whereby land that had earlier been common became the property of private landowners. As a consequence, a large number of people had to leave the countryside to work in the emerging industrial sectors in urban areas [see e.g. Clarkson 1971, Dillard 1967 and Rider 1995].

${ }^{15}$ Ogilvie [2000, p. 125] also states "Elsewhere on the continent /compared to England/ neither markets nor states made much of a start on improving land transportation until the late eighteenth century".

${ }^{16}$ The question as to why England developed a better infrastructure goes beyond the scope of this paper. However, England did not possess a technological advantage over France. One reason may instead be that the French bureaucracy was too rigid to be able to develop the infrastructure [Szostak 1991]. Moreover, entrenched political elites may not have favored economic development due to their fear of losing rents
} 
When transportation is poor and government officials control vast areas, citizens as well as government officials can easily avoid detection; they will not be detected unless monitoring costs are low [Weber 1968]. One of the binding pre-industrial restrictions, for example, was probably poor control of territorial perimeters. As messages, officials, etc. moved slowly, it was difficult to control the far ends of large countries [Finer 1997]. As Kiser and Kane [2001, p. 214] write: "The timing of the bureaucratization of indirect taxes in France lagged far behind that in England. This difference can be traced primarily to the monitoring problems caused by size and the slower development of communications and transportation technology."

In consequence, we would expect theft to be rare and monitoring to be common within the English administration, and theft to be common and monitoring rare within the French administration. This is supported by Swart [1980], Brewer [1988] and Kiser and Kane [2001]. For the case of England, Brewer [1988, p. 108], for example, notes: "The idle officer was discouraged by the high probability of detection and punishment". ${ }^{17}$ As regards France, Kiser and Kane [2001, p. 203] state: "Prior to the significant development of communications and transportation technologies in France around 1780...the monitoring capacity of French rulers was too limited to control fixed provincial officials." 18

Historical evidence also shows that the default risk in England and France diverged around the time of the Glorious Revolution in 1688.

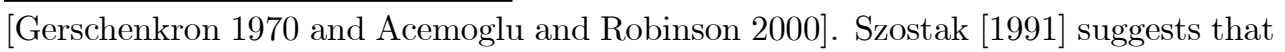
this can explain why the French infrastructure developed so slowly.

${ }^{17}$ We note, however, that remote areas of England, such as Scotland, sometimes escaped taxation [O'Brien 1988].

${ }^{18}$ For example, in the sixteenth century, it took three weeks to get from Paris to Lyon. In the seventeenth century, Paris to Toulouse took fourteen days. In 1765 it still took ten - sixteen days to get from Paris to the edges of France [Kiser 1994]. 
Before the Revolution, both the English and the French monarchs often defaulted on their loans [see e.g. Ekelund and Tollison 1981, Brewer 1988, North and Weingast 1989, Bordo and White 1991 and Velde and Weir 1992]. Velde and Weir [1992, p. 5], for example, find that: "Prior to 1688, both monarchies / England and France / resorted to default in times of fiscal crisis". Brewer [1988, p. 20] states that before 1688 in France: "In a crisis, the fiscal prudence of rulers was thrown to the winds, the long-term liability of venality overlooked in the headlong rush for immediate funds".

After the Revolution, this tradition was stopped in England but not in France and the credibility of the English Parliament was far higher than that of the French monarchs. According to Stasavage [2002, p. 164], for example, "English governments after 1688 did, on average, improve their credibility with regard to debt repayment when compared with their predecessors". When discussing France, Stasavage [2002, p. 177] instead finds: "...there is ample evidence to show that the French government lacked credibility as a borrower throughout the eighteenth century". Ferguson [2001, p. 172], for example, writes that in contrast to England "French yields in the eighteenth and nineteenth centuries reveal starkly the impact of fiscal unreliability on investor confidence". To quote Matthews [1958, p. 9] "On its own credit backed by the profits derived from an exploitation of the General Farms, the Company borrowed from those who, for good reasons, were reluctant to lend directly to the /French/ king."

Two reasons why the English Parliament was more credible than the French monarchs are given by North and Weingast [1989] and Bordo and White [1991]. North and Weingast [1989] argue that after the Glorious Revolution, checks and balances emerged among the parliament, the ju- 
diciary and the king in England, which raised the predictability of the government. Bordo and White [1991] similarly argue that English institutions such as checks and balances and the Bank of England, enhanced credibility compared to France.

Lenders want a high risk premium when the credibility of the borrower is low. In line with what we would expect, historical data confirms that the interest rate was typically high both in France and England before the Glorious Revolution, and low afterwards in England but still high in France. In the first half of the seventeenth century, the English monarchs typically paid 10-14 percent on their loans, and in the second half the interest was 6-12 percent. Even though the French monarchs seem to have borrowed at low interest rates, 3.5-5 percent, in the first half of the seventeenth century, the interest rate in the second half was 5-7 percent and sometimes as high as above 14 percent [Homer 1963, Epstein 2000]. ${ }^{19}$ After the Glorious Revolution, the interest rate fell steeply in England and fluctuated between 3 and 5 per cent during the eighteenth century [North and Weingast 1989, Weir 1989, Bordo and White 1991, Velde and Weir 1992, White 1995 and Clark 2000]. ${ }^{20}$ This is in sharp contrast to the conditions in France, where the interest rate was always higher, rarely below 5 per cent, and sometimes much higher, up to 13 per cent [Homer 1963, Velde and Weir 1992, Epstein 2000 and Ferguson 2001].

This discrepancy seems to have been due to differences in the default risk. Velde and Weir [1992] show that the market interest rate was similar in England and France, in the 4-5 percent range, and argue that

\footnotetext{
${ }^{19}$ It is difficult to collect information about market interest rates in this early period and the default risk premium is therefore also difficult to measure.

${ }^{20}$ This rate was often below the market interest rate, indicating that the English government was highly credible [Clark 2000].
} 
the difference in interest rates for government borrowing: "cannot be easily attributed to any other source than default risk" [1992, p. 5]. Bordo and White [1991] also argue that the persistent default risk of French monarchs gave rise to the large differences in interest rates for government borrowing. ${ }^{21}$ In support of this thesis, Quinn [2001, p. 593] writes: "The Glorious Revolution's political settlement appears to have reduced the risk premium on sovereign debt". Ferguson [2001, p. 172] finds that, in contrast to England, "French yields in the eighteenth and nineteenth centuries reveal starkly the impact of fiscal unreliability on investor confidence" ${ }^{22}$

\section{THE MODEL}

We consider the provision of a single homogeneous governmental good and define it as issuing a permit. An agent (government official or private monopolist) has the sole right to provide, and the opportunity to restrict, the quantity of permits. We think of the agent as a tax-collector who charges a tax which citizens must pay in order to produce or consume. But the model could equally well reflect the sale of permits and licences,

\footnotetext{
${ }^{21}$ The French royal government defaulted wholly or partially on their loans in 1698 , 1714, 1721, 1759, 1770 and 1788 [Ferguson 2001].

${ }^{22} \mathrm{~A}$ different explanation, however, is given by Epstein [2000] who argues that the decline in English interest rates was the result of the country's financial revolution rather than of a revolution in political freedom and rights. Another explanation is given by Weir [1989] who argues that the French interest rate was high because the monarchs wanted to subsidize the urban middle class that lent the money. In this paper, we show that a high interest rate is not a suitable instrument for subsidies since it reduces the rents that can be extracted through tax collection. Yet another explanation is provided by Hicks [1969] who argued that, compared to absolutisms, the relative continuity provided by the English Parliamentarism promoted low interest rates.
} 
which were common in Europe at the time. ${ }^{23}$

Citizens have a linear inverse demand for the permits. The demand curve is given by

$$
p(q)=a-b q
$$

where $a$ and $b$ are constants, $q$ is the number of permits allocated by the agent and $p$ is the price of the permits (or equivalently the tax rate). A central authority (CA) uses the agent to extract rents from consumers. He sells offices in an auction for up-front payments, and may demand a fee, $\theta$, per each permit sold by the agent, which is paid ex post. The agent can, as in Shleifer and Vishny [1993], issue permits without paying the CA but may then get caught by the CA, who monitors at the cost $c$ and penalizes him. ${ }^{24}$ The penalty is assumed to be constrained by limited liability on the part of the agent and amounts to $t=\bar{t}$.

There are two time periods and the CA maximizes his disposable income. What the CA cannot extract ex ante it will borrow. However, the CA cannot borrow more than the net present value of its ex-post incomes. The CA-specific interest rate is given by $\delta$. The offices are sold through a first price sealed bid auction. Agents must also borrow in order to buy the the position. The interest rate to which a potential agent $i$ can borrow is given by $r_{i}$ and is privately known. It is assumed that $R_{i}=\frac{1}{1+r_{i}}$ is uniformly distributed on $[0,1] .{ }^{25}$ The strategy space for the $n$ bidders is $R_{i} \epsilon[0,1]$ and they are assumed to use linear strategies

\footnotetext{
${ }^{23}$ See e.g. Lipson [1948], Binney [1958], Hill [1970] and Brewer [1988].

${ }^{24}$ In theory, the CA knows if theft has occurred and would not need to monitor. However, monitoring may be needed to verify theft. Moreover, it may well be that the official steals and then promptly leaves the position. To prevent this, the CA needs to monitor the official.

${ }^{25}$ For simplicity we normalize the market-interest rate to zero and let the interest rate be a function of each agent's default risk solely.
} 
$B_{i}\left(R_{i}\right)=\alpha_{i} R_{i} \pi^{*}$ where $R_{i} \pi^{*}$ is the expected value of the office.

The decisions in the model are taken in the following order: first, the CA selects the system of rent extraction through the fee $\theta$, followed by potential agents bidding for the office. Then, the theft and monitoring decisions are made. After that, the agent chooses the quantity, $q$, and finally, the potential penalties are enforced. The game is solved by backward induction starting at stage four when the agent sells the permits.

\section{III.A. Stage Four: the Market for Permits}

The agent's problem is to maximize his profit with respect to the number of permits provided

$$
\max _{q} \pi=(a-b q) q-\theta q
$$

The fee per permit, $\theta$, which the agent has to pay to the CA is determined by the CA. The equilibrium number of permits is equal to

$$
q^{*}(\theta)=\frac{a-\theta}{2 b}
$$

and the equilibrium price is given by

$$
p^{*}(\theta)=\frac{a+\theta}{2} .
$$

Thus, the profit for the agent is equal to

$$
\pi^{N T}(\theta)=\frac{(a-\theta)^{2}}{4 b}
$$

where the superscript $N T$ denotes a no theft case. In the case of theft, the agent issues permits without compensating the CA. Hence, the agent receives the profit

$$
\pi^{T}=\frac{a^{2}}{4 b}
$$

where the superscript $T$ denotes theft. 


\section{III.B. Stage Three: Theft and Enforcement}

At stage three, the CA decides whether to monitor the agent or not and the agent decides whether to steal or not. The payoffs determining the monitoring and theft decisions are shown in Figure 1.

\begin{tabular}{c|l|c|l|}
\multicolumn{3}{c}{ Central Authority } \\
\cline { 2 - 4 } Agent & \multicolumn{1}{c}{ Monitor } & Not Monitor \\
\cline { 2 - 4 } & Theft & $\pi^{T}-t, t-c$ & $\pi^{T}, 0$ \\
\cline { 2 - 4 } & No Theft & $\pi(\theta)^{N T}, \theta q(\theta)-c$ & $\pi(\theta)^{N T}, \theta q(\theta)$ \\
\hline
\end{tabular}

Figure 1. The Game between the Agent and the Central Authority

We assume that the agent has some wealth in addition to the revenues he earns from stealing $\pi^{T}$, i.e., $t>\pi^{T}$ and that $t>c$ so there are no pure strategy equilibria of the game. We solve for the mixed strategy equilibrium that would make the $\mathrm{CA}$ indifferent between monitoring and not monitoring, and the agent indifferent between stealing and not stealing. The threshold probability of theft that would make the CA indifferent between monitoring and not monitoring, $\mu$, becomes

$$
\mu=\frac{c}{t}
$$

In equilibrium, the higher the monitoring cost, the higher is the probability of theft.

The threshold probability of monitoring that would make the agent indifferent between theft and no theft, $\gamma$, is equal to

$$
\gamma=\theta \frac{2 a-\theta}{4 t b}
$$

The CA's expected profits from fees, $\pi^{F}$, are in equilibrium equal to

$$
\begin{aligned}
\pi^{F} & =\mu \gamma(t-c)+(1-\mu) \gamma(\theta q(\theta)-c)+(1-\gamma)(1-\mu) \theta q(\theta)= \\
& =(1-\mu) \theta q(\theta)
\end{aligned}
$$


Note that the incomes from the penalty in equilibrium exactly cover the monitoring cost. Because the agent is held indifferent between theft and no theft, his equilibrium profit will be the value of no theft

$$
\pi^{*}(\theta)=\frac{(a-\theta)^{2}}{4 b}
$$

However, since these revenues are collected ex post, the net present value of the game for agent $i$ is equal to

$$
\pi_{i N P V}^{*}(\theta)=\frac{\pi^{*}(\theta)}{1+r_{i}}=R_{i} \pi^{*}(\theta)
$$

\section{III.C. Stage Two: the Choice of Agents}

At stage two, the CA sells the office. We assume that $n$ identical potential agents compete for office by way of paying the CA up front in a first price sealed bid auction. The best reply function of bidder $i$ solves:

$$
\max _{B_{i}}\left(\frac{(a-\theta)^{2}}{4 b} R_{i}-B_{i}\right) \operatorname{Pr}\left(B_{j} \leq B_{i}\right)^{n-1} \forall j=1 \ldots n, j \neq i
$$

For the uniform distribution, this implies

$$
\max _{B_{i}}\left(\frac{(a-\theta)^{2}}{4 b} R_{i}-B_{i}\right)\left(\frac{B_{i}}{\alpha_{j}}\right)^{n-1}
$$

The optimal bid is equal to

$$
B_{i}^{*}=\frac{n-1}{n} \frac{(a-\theta)^{2}}{4 b} R_{i}
$$

The CA's expected up-front payment is given by ${ }^{26}$

$$
E\left(B_{i}^{*}(\theta)\right)=\frac{n-1}{n} \frac{(a-\theta)^{2}}{4 b} E\left(R_{i}\right)=\frac{n-1}{n+1} \frac{(a-\theta)^{2}}{4 b} .
$$

\footnotetext{
${ }^{26}$ The CA's expectation of the winner's interest rate is the maximum $R^{1}$ of the sample of size $n$, which has the distribution $F^{1}(R)=R^{n}$. The expected value is therefore $E\left(R^{1}\right)=\int_{0}^{1} R n R^{n-1} d R=\frac{n}{n+1}$. Hence, the CA's expected income from the sale of the office is given by $E\left(B_{i}^{*}(\theta)\right)=\frac{n-1}{n+1} \frac{(a-\theta)^{2}}{4 b}$.
} 
This auction mechanism is, as long as $n$ does not go to infinity, inefficient from the CA's perspective because the interest rates are private information. When a potential agent selects a bid below his true value of the office, he can win and the rent, if won, is increasing from zero to a positive amount.

\section{III.D. Stage One: The Choice of System of Rent Extraction}

We now analyze the CA's choice of rent-extraction system, which we interpret to be reflected by the choice of $\theta$. In a system of direct collection by government officials, they first extract the rents and then provide them to the CA. In terms of our model, this system is mimicked by a high $\theta$, as it generates large ex-post revenues to the CA and small rents on part of the agent who therefore pays the CA small up-front payments. When monopoly rights are granted to private contractors, in contrast, they typically pay the CA before, rather than after, they have extracted the rents. A low $\theta$ reflects this system since the agent's profit, and hence up-front payment, is large whereas the CA's ex-post income is low.

The CA maximizes his disposable incomes, or in other words, the net present value of its two-period flow of incomes. It collects the winning bid for the office, $\frac{n-1}{n+1} \frac{(a-\theta)^{2}}{4 b}$, up front and borrows as much as possible. The $\mathrm{CA}$ is also assumed to be credit constrained, which restricts it to borrow the net present value of its ex post collection of fees, i.e., $\frac{\left(1-\frac{c}{t}\right) \theta \frac{(a-\theta)}{2 b}}{1+\delta}$. We initially assume that the CA can commit to its ex-ante announcement of the fee.

When selecting the optimal system of rent extraction, the CA therefore has the following problem: 


$$
\max _{\theta} \Pi_{N P V}=\frac{n-1}{n+1} \frac{(a-\theta)^{2}}{4 b}+\frac{\left(1-\frac{c}{t}\right) \theta \frac{(a-\theta)}{2 b}}{1+\delta} .
$$

The optimal fee is equal to ${ }^{27}$

$$
\theta^{*}=\frac{a}{2}\left(1-\frac{1+\delta}{\frac{2\left(1-\frac{c}{t}\right)}{\frac{n-1}{n+1}}-(1+\delta)}\right) .
$$

We can now show how the monitoring cost and the default risk affect the choice of system of rent extraction.

Proposition 1 The higher (lower) the monitoring cost, $c$, and default risk, $\delta$, the lower (higher) is the fee $\theta$, i.e., the more is up-front (ex-post) collection used.

Proof. The derivatives

$$
\frac{\partial \theta^{*}}{\partial \delta}=-\frac{a}{2} \frac{\frac{2\left(1-\frac{c}{t}\right)}{\frac{n-1}{n+1}}}{\left(\frac{2\left(1-\frac{c}{t}\right)}{\frac{n-1}{n+1}}-(1+\delta)\right)^{2}}<0
$$

and

$$
\frac{\partial \theta^{*}}{\partial c}=-a \frac{\frac{n-1}{n+1}(1+\delta)}{t\left(2\left(1-\frac{c}{t}\right)+(1+\delta) \frac{n-1}{n+1}\right)^{2}}<0
$$

prove the proposition.

When shaping the rent-extraction system, the CA weighs the costs and benefits of up-front collection relative to ex-post collection. The cost of using up-front collection is that the full value of the office cannot be collected due to the auction mechanism. The cost of using ex-post payments is that the agent might steal and that it is costly to borrow.

A high monitoring cost, $c$, generates much theft such that the ex-post revenues and the amount that can be borrowed are low. Similarly, only a small amount can be borrowed when the default risk, $\delta$, is high. In both

\footnotetext{
${ }^{27}$ For $\theta^{*}>0$, it is necessary that $1+\delta>\frac{1-\frac{c}{t}}{\frac{n-1}{n+1}}$.
} 
cases, the CA selects a low fee to enhance the agents's profit and in turn his up-front payments. In other words, the CA selects a system of private contracting. When the default risk and the monitoring cost are low the ex-post incomes are large. To exploit this fact, the CA uses a high fee, i.e., it selects a system of direct collection within the government.

We next consider the distributional aspects of the model. The CA's net present value is given by

$$
\Pi_{N P V}=\frac{\left(1-\frac{c}{t}\right)^{2}}{(1+\delta)\left(2\left(1-\frac{c}{t}\right)-\frac{n-1}{n+1}(1+\delta)\right)} \pi^{T},
$$

and the agent's profit is equal to

$$
\pi_{N P V}^{*}=\frac{\frac{2}{n+1}\left(1-\frac{c}{t}\right)^{2}}{\left(\frac{n-1}{n+1}(1+\delta)-2\left(1-\frac{c}{t}\right)\right)^{2}} \pi^{T} .
$$

The expected price level is equal to

$$
E\left(p^{*}\right)=\frac{c}{t} \frac{a}{2}+\left(1-\frac{c}{t}\right) \frac{a+\theta^{*}}{2} .
$$

The debt, finally, is given by

$$
\text { Debt }=2 \frac{\left(1-\frac{c}{t}\right)^{2}\left(\frac{1-\frac{c}{t}}{1+\delta}-\frac{n-1}{n+1}\right)}{\left(\frac{n-1}{n+1}(1+\delta)-2\left(1-\frac{c}{t}\right)\right)^{2}} \pi^{T} .
$$

We can now study how the default risk and the monitoring cost affect these variables.

Proposition 2 The higher the default risk, $\delta$, and the larger the monitoring cost, $c$, the higher is the agent's profit and the lower is the value of the central authority's incomes, the debt issued and the price level.

Proof. See Appendix.

When the default risk and the monitoring costs are high the CA reduces the fee, $\theta$, to increase the agent's profit and consequently up-front 
payment. In other words, the agent's profit is high because the CA wants it this way. Independently of the choice of system of rent-extraction, the debt issued will be small as investors expect low ex-post incomes. In addition, since a system of up-front payments is selected the debt issued is even smaller. The CA's rent is low even though it adjusts the system of rent-extraction to the unfavorable conditions. When the default risk and monitoring costs are low, a high fee is used which reduces the agent's profit. The debt and the CA's profit are large as we would expect, and further enhanced by the fact that ex-post collection is adopted.

Our theory thus reflects the historical facts well. Before the midseventeenth century, the conditions were not favorable for direct collection neither in France nor in England. ${ }^{28}$ During this time, the public finances were poor and tax farmers and monopolists' rents large [Brewer 1988, Swart 1980]. As the cost of monitoring officials in England was reduced, ex-post collection became more attractive. Consequently, England started to change the system of revenue collection after the Civil War in 1640. As O'Brien [2002, p. 262] writes, the fiscal system started to change "when its /England's/ domestic economy began to generate the kind of accelerated urbanization, commercialization, and concentration that facilitated the collection of duties on domestic production and imports". But this change was partial; offices were still sold [Brewer 1988]. Not until after the Glorious Revolution, when the English default

\footnotetext{
${ }^{28}$ Matthews [1958] writes "The late-medieval $\backslash$ French $\backslash$ monarchy was not equipped to deal with individuals in their guise as producers, wholesalers, retailers, merchants, and consumers. The complicated activity of an economy of buying and selling was too diffuse yet too localized, too subject to unforeseen changes, for a rudimentary government to cope with on a centralized basis...Consequently, as taxes (such as excises and customs duties) which required intensive bureaucratic management were levied, they were farmed".
} 
risk was substantially reduced, was the system of up-front collection of rents abandoned, with the consequence of a dramatic increase in the incomes from taxation, the debt issued, and reduction in the income of the officials [Weir 1989, Bordo and White 1991 and Brewer 1988].

In the eighteenth century in France, in contrast, the default risk and monitoring cost were still very high [Homer 1963 and Kiser and Kane 2001], the public finances poor [Brewer 1988 and Ekelund and Tollison 1981], and oligarchs could "cream off huge fortunes at the expense of the monarch and the public" [Brewer, 1988 p. 130]. At this time, privileges and perquisites were at least four times higher in France than in England [Brewer 1988, see also Kiser and Kane 2001]. Even after the French Revolution, French officials had to pay a sum ranging from three to five times their salary to buy their job [Zeldin 1973]. ${ }^{29}$

We finally examine the model's implications regarding the probabilities of monitoring and theft against historical evidence. It follows from $\frac{\partial \mu}{\partial c}=\frac{1}{t}>0$ and $\frac{\partial \gamma}{\partial c}=2 \frac{\partial \theta}{\partial c} \frac{a-\theta}{4 t b}<0$ that an increase in the monitoring cost increases the equilibrium probability of theft and, because the variable fee is reduced, leads the CA to monitor with a lower probability. Similarly, as $\frac{\partial \gamma}{\partial \delta}=2 \frac{\partial \theta}{\partial \delta} \frac{a-\theta}{4 t b}<0$, an increase in the default risk will reduce the probability of monitoring. It will, however, not affect the probability of theft.

As the theory predicts, the rate of theft and of level of monitoring were remarkable low in England during the eighteenth century [Swart

\footnotetext{
${ }^{29}$ If indirect taxation was cumbersome in France, one may ask why the French monarchs not turned to direct taxation. To some extend they did but they faced restrictions there as well. Many of the rich were for historical reasons exempted. There were also political restrictions because direct taxation was considered particularly unfair. Moreover, the collection of direct taxes was cumbersome as well because the valuation of land and properties was difficult.
} 
1980, Brewer 1988 and Kiser and Kane 2001] and high in France [Kiser and Kane 2001]. Brewer [1988] writes at length about the extensive monitoring in the English administration and how officials were discouraged to steal from the government. ${ }^{30}$ Brewer also reports that the number of "supervisors", supervising officials, increased by 469 percent from 1690 to 1780 whereas the number of excise officials increased by only 280 percent, which indicates that the probability of monitoring significantly increased in this period.

\section{Robustness Analysis: Commitment to the Fee}

If the CA could not commit to investors, it may not have been able to credibly commit to its own officials. As a check for robustness, we therefore include the possibility that the $\mathrm{CA}$ cannot commit to the variable fee, $\theta$.

Assume that the CA can commit to the fee, $\theta$, with probability $(1-\lambda)$. With probability $\lambda$ the CA will take $\theta s$ instead where $s>1 .{ }^{31}$ From the official's ex-ante perspective, the expected fee is therefore equal to $\theta((1-\lambda)+\lambda s)$. The equilibrium number of permits provided by the agent is in this augmented model equal to $q^{*}(\theta)=\frac{a-\theta(1-\lambda+\lambda s)}{2 b}$ and the CA's expected up-front payment is $\varepsilon\left(B_{i}^{*}(\theta)\right)=\frac{n-1}{n+1} \frac{(a-\theta(1-\lambda+\lambda s))^{2}}{4 b}$. The amount the CA can borrow ex ante is given by the net present value of its

\footnotetext{
${ }^{30}$ Contemporaries for example described the Excise as "the monster that has ten thousand eyes and condemned the excise man as watchful to excess." [Brewer, 1988 p. 113] Brewer also writes colorfully "An officer's supervisor was likely to swoop into his round at any moment, take up the exciseman's entry book and follow him on his journey, checking his gauges and ensuring that he had left specimen papers at the premises he had declared he would inspect." [Brewer, 1988 p. 109]

${ }^{31}$ An absolutistic central authority would expropriate the official's whole profit ex post. We assume that it is not absolutistic and it can therefore only take $\theta s$.
} 
expected ex-post collection of the announced fees: $\frac{\left(1-\frac{c}{t}\right)}{1+\delta} \theta \frac{a-\theta(1-\lambda+\lambda s)}{2 b} .32$

At stage one, the CA therefore solves

$$
\max _{\theta} \frac{n-1}{n+1} \frac{(a-\theta(1-\lambda+\lambda s))^{2}}{4 b}+\left(1-\frac{c}{t}\right) \theta \frac{a-\theta(1-\lambda+\lambda s)}{(1+\delta) 2 b} .
$$

The solution is

$$
\theta^{*}=\frac{a}{2(1-\lambda+s \lambda)}\left(1-\frac{\frac{n-1}{n+1}(1-\lambda+s \lambda)}{\varphi}\right) .
$$

where $\varphi \equiv 2 \frac{\left(1-\frac{c}{t}\right)}{(1+\delta)}-\frac{n-1}{n+1}(1-\lambda+s \lambda)>0$ for a solution to exist.

The agent's profit is equal to

$$
\pi_{N P V}^{*}=\frac{2}{n+1} \frac{\left(1-\frac{c}{t}\right)^{2}}{\varphi^{2}(1+\delta)^{2}} \pi^{T}
$$

the CA's profit is equal to

$$
\Pi_{N P V}=\frac{\left(1-\frac{c}{t}\right)^{2}}{(1+\delta)(1-\lambda+s \lambda) \varphi} \pi^{T},
$$

and the debt is given by

$$
D e b t=\frac{\left(1-\frac{c}{t}\right)^{2}\left(\frac{n-1}{n+1}(1-\lambda+s \lambda)-\frac{1-\frac{c}{t}}{1+\delta}\right)}{\varphi^{2}(1-\lambda+s \lambda)} 2 \pi^{T} .
$$

Proposition 3 An increase in the probability to commit to the agent increases the use of ex-post payments, the debt issued and the CA's profits, and reduces the agent's rent.

Proof. See Appendix.

Consider an increase in the probability to commit to the agent, i.e., a reduction in $\lambda$. The CA's response is to increase the announced fee such the agent's expected profit is reduced. In other words, the CA increases the use of direct collection within the government. This change increases

\footnotetext{
${ }^{32}$ To emphasize that the default risk, $\delta$, and the probability to commit to officials, $\lambda$, yield the same qualitative results we treat them as independent of each other.
} 
the debt issued (even though the expected quantity is reduced). The net present value of the CA's income increases both directly and through the adjustment of the rent-extraction mechanism.

This extension of the model, which takes into account not only the CA's probability to commit to investors but also the probability to commit to its public officials, is consistent with the historical evidence. The French monarchs' best response to their low probability to commit was to use up-front payments in a system of tax farming. The English Parliament, in contrast, could commit to its decisions and therefore found ex-post payments by government officials attractive.

\section{Conclusions}

In this paper, we propose a new perspective on the system of taxation in England in the second half of the seventeenth and the beginning of the eighteenth century, when a changeover to direct collection gave rise to better public finances than the system of its major competitor, France. In our model, the leading regime extracts rents from taxation or agents' sales of government goods, such as permits, either through up-front payments or through ex-post payments based on the quantity of goods officials sell. Both interest rates on government borrowing and monitoring costs influence which scheme politicians prefer. Owing to their higher default risk, French monarchs faced higher interest rates on borrowing than the English Parliament. In response, they continued to use tax-farming and grant monopoly rights, which led to large rents to the contractors and small incomes for the monarchs. In addition, since monitoring costs were higher in France, fees were cumbersome to extract, which also made the granting of monopolies more attractive. In England, in contrast, fees were collected ex post within the govern- 
ment administration, which implied small revenues to officials and large revenues to the leaders.

In other words, France adopted an institutional design where the monarch and oligarchs divided the surplus among themselves. In England, Parliament extracted the surplus from taxation at the expense of oligarchs and officials. According to our theoretical model, then, the institutional reform, which led to better public finances, was not a result of a benevolent parliament, but rather the outcome of opportunistic behavior on the part of parliamentarians who were sufficiently powerful in shaping institutions for their private benefit. In England, this turned out to provide a favorable climate for industrialization. In France, the circumstances eventually led to revolution. 


\section{APPENDIX}

\section{Proof of Proposition 1}

The condition for a solution to the CA's problem is

$$
\psi=\frac{n-1}{n+1}(1+\delta)-2\left(1-\frac{c}{t}\right)<0
$$

For $\theta>0$ it is also necessary that

$$
\kappa=\frac{n-1}{n+1}(1+\delta)-1+\frac{c}{t}<0
$$

Higher monitoring costs and default risk reduces the CA's profit because

$$
\frac{\partial \Pi_{N P V}^{*}}{\partial \delta}=\frac{\left(1-\frac{c}{t}\right)^{2} \kappa}{(1+\delta)^{2} \psi^{2}} 2 \pi^{T}<0
$$

and

$$
\frac{\partial \Pi_{N P V}^{*}}{\partial c}=\frac{\left(1-\frac{c}{t}\right) \kappa}{t(1+\delta) \psi^{2}} 2 \pi^{T}<0 .
$$

The agent's profit is increased since

$$
\frac{\partial \pi_{N P V}^{*}}{\partial c}=-\frac{n-1}{(n+1)^{2}} \frac{\left(1-\frac{c}{t}\right)(1+\delta)}{\psi^{3} t} 4 \pi^{T}>0,
$$

and

$$
\frac{\partial \pi_{N P V}^{*}}{\partial \delta}=-\frac{n-1}{(n+1)^{2}} \frac{\left(1-\frac{c}{t}\right)^{2}}{\psi^{3}} 4 \pi^{T}>0 .
$$

The debt finally is reduced due to an increase in the monitoring costs and default risk because

$$
\frac{\partial D e b t}{\partial \delta}=\left(\frac{\left(\frac{n-1}{n+1}\right)^{2}+\frac{\kappa \psi}{(1+\delta)^{2}}}{\psi^{3}}\right)\left(1-\frac{c}{t}\right)^{2} 2 \pi^{T}<0
$$

and

$$
\frac{\partial D e b t}{\partial c}=\left(\frac{n-1}{n+1}\right)^{2} \frac{\left(1-\frac{c}{t}\right)(1+\delta)}{t \psi^{3}} 2 \pi^{T}<0
$$


Proof of Proposition 2

A higher probability to commit leads to more tax-farming since

$$
\frac{\partial \theta^{*}}{\partial \lambda}=-\frac{s-1}{s \lambda-\lambda+1}\left(\frac{2\left(1-\frac{c}{t}\right) \frac{n-1}{n+1} a}{(1+\delta) \varphi^{2}}+\theta^{*}\right)<0
$$

where $\varphi>0$.

The official's profit is increased because

$$
\frac{\partial \pi_{N P V}^{*}}{\partial \lambda}=\frac{(1+\delta)(s-1)\left(\frac{2}{n+1}\right)\left(1-\frac{c}{t}\right)^{2} \frac{n-1}{n+1}}{\varphi^{3}} 2 \pi^{T}>0 .
$$

The CA's profit is reduced as

$$
\frac{\partial \Pi_{N P V}^{*}}{\partial \lambda}=-\frac{\left(1-\frac{c}{t}\right)^{2}(s-1)\left(1-\frac{c}{t}-\frac{n-1}{n+1}(1+\delta)(s \lambda-\lambda+1)\right)}{(1+\delta)(s \lambda-\lambda+1)^{2} \varphi^{2}} 2 \pi^{T}<0
$$

where $1-\frac{c}{t}-\frac{n-1}{n+1}(1+\delta)(s \lambda-\lambda+1)>0$ for $\theta>0$.

The debt, finally, is reduced since

$$
\frac{\partial D e b t}{\partial \lambda}=\frac{\partial \theta^{*}}{\partial \lambda}\left(\frac{a-2 \theta^{*}(1-\lambda+\lambda s)}{2 b}\right)-\theta^{*} \theta^{*}(s-1)<0 .
$$




\section{References}

[1] Acemoglu, Daron and Robinson, James A. (2000), "Political Losers As a Barrier to Economic Development," American Economic Review Papers and Proceedings 90: 126-130.

[2] Becker Gary and Stigler Georg J. (1974), "Law Enforcement, Malfeasance, and Compensation of Enforcers," Journal of Legal Studies 3: 1-18.

[3] Binney, John E. D. (1958), British Public Finance and Administration 1774-92 (Clarendon Press, Oxford).

[4] Bordo, Michael D. and White, Eugene N. (1991), "A Tale of Two Currencies: British and French Finance During the Napoleonic Wars," Journal of Economic History 51: 303-316.

[5] Braddick Michael (1996), The Nerves of State: Taxation and the Financing of the English State, 1558-1700, (Manchester University Press, Manchester).

[6] Brewer John (1988), The Sinews of Power, War, Money and the English State 1688-1783 (Harvard University Press, Cambridge Mass.).

[7] O'Brien, Patrick K. (1988), "The Political Economy of British Taxation, 1660-1815," Economic History Review 41: 1-32.

[8] O'Brien Patrick K. and Hunt Philip A. (1999), "England 14851815," in The Rise of the Fiscal State in Europe, Bonney Richard (ed), (Oxford University Press, Oxford).

[9] O’Brien Patrick (2002), "Fiscal Exceptionalism: Great Britain and its European Rivals from Civil War to Triumph at Trafalgar and Waterloo," in The Political Economy of British Historical Experience, 1688-1914, Winch Donald and O'Brien Patrick (eds), (Oxford University Press, Oxford). 
[10] Carmichael Lorne (1985), "Can Unemployment be involuntary?" American Economic Review 75: 1213-1214.

[11] Chandaman, C. D. (1975), The English Public Revenue 1660-1688 (Oxford University Press, Oxford).

[12] Clark, Gregory (2000), "Debt, Deficits, and Crowding Out: England, 1727-1840," European Review of Economic History 5: 403436.

[13] Clarkson, L. A. (1971), The Pre-Industrial Economy in England 1500-1750 (B. T. Batsford LTD, London).

[14] De Vries, Jan (1984), European Urbanization 1500-1800 (Harvard University Press, Cambridge Mass.).

[15] Dickens, William T, Katz Lawrence F, Lang Kevin and Summers Larry (1989), "Employee Crime and the Monitoring Puzzle," Journal of Labor Economics, 7: 331-47.

[16] Dillard, Dudley (1967), Economic Development of the North Atlantic Community: Historical Introduction to Modern Economics (Prentice Hall, Englewood Cliffs, N.J.).

[17] Ekelund, Robert B. and Tollison, Robert D. (1981), Mercantilism as a Rent-Seeking Society, Texas A\&M University Economics series, no 5 .

[18] Epstein, Stephan, (2000), Freedom and Growth: The Rise of States and Markets in Europe, 1300-1750 (Routledge, London).

[19] Ferguson, Niall (2001), The Cash Nexus - Money and Power in the Modern World, 1700-2000 (Basic Books, New York).

[20] Finer, Samuel (1997), The History of Government, vol. I-III (Cambridge University Press, Cambridge, U.K.).

[21] Gerschenkron, Alexander (1970), Europe in the Russian Mirror: Four Lectures in Economic History (Cambridge University Press, 
Cambridge, U.K.).

[22] Hart, Oliver, Shleifer, Andrei and Vishny, Robert W. (1997) "The Proper Scope of Government: Theory and an Application to Prisons," Quarterly Journal of Economics, 112: 1127-1161.

[23] Hicks, John R. (1969), A Theory of Economic History (Oxford University Press, Oxford).

[24] Hill, C.P. (1970), British Economic and Social History (Edward Arnold Ltd., London).

[25] Hoffman, Walther (1965), Das Wachstum der deutschen Wirtschaft seit der Mitte des 19. Jahrhunderts (Springer Verlag, Berlin).

[26] Homer, Sidney (1963), A History of Interest Rates (Rutger University Press, New Brunswick, N.J.).

[27] Johnson Noel D. (2003), "Banking on the King: The Evolution of The Royal Revenue Farms in Old Regime France," Mimeo, California State University.

[28] Laffone Jean-Jacques, and Tirole Jean (1993), A Theory of Incentives in Procurement and Regulation, (MIT Press, Cambridge, Mass).

[29] Lipson, Ephraim (1948), The Economic History of England (R\&R Clark LTD, Edinburgh).

[30] Kiser, Edgar and Kane, Joshua (2001), "Revolution and State Structure: The Bureaucratization of Tax Administration in Early Modern England and France," American Journal of Sociology 107: $183-223$.

[31] Matthews, George T. (1958), The Royal General Farms in Eighteenth-Century France (Columbia University Press, NY).

[32] North, Douglas C. and Thomas, Robert P. (1973), The Rise of the Western World (Cambridge University Press, Cambridge, U.K.). 
[33] North, Douglas C. (1981), Structure and Change in Economic History (W \& W Norton and Company, Inc., New York, NY).

[34] North, Douglas C. and Weingast, Barry R. (1989), "Constitutions and Commitment: Evolution of Institutions Governing Public Choice in 17th Century England," Journal of Economic History 49: 803-832.

[35] Ogilvie, Sheilagh (1999) "The State in Germany - A Non-Prussian View," in Rethinking Leviathan - The Eighteenth-Century State in Britain and Germany, Brewer John and Eckhart Hellmuth (eds.) (Oxford University Press, Oxford).

[36] Ogilvie, Sheilagh (2000), "The European Economy in the Eighteenth Century," in The Eighteenth Century 1688-1815, Blanning, Tim C.W. (ed.), (Oxford University Press, Oxford).

[37] Olson, Mancur (1993), "Dictatorship, Democracy, and Development," American Political Science Review 87: 567-576.

[38] Quinn, Stephen (2001), "The Glorious Revolution's Effect on English Private Finance: A Microhistory, 1680-1705," Journal of Economic History 61: 593-615.

[39] Rider, Christine (1995), An Introduction to Economic History (South-Western College Publishing, Cincinnati, Kentucky.).

[40] Rose-Ackerman, Susan (1978), Corruption: A Study in Political Economy (Academic Press, New York, NY).

[41] Schmidt, Klaus (1996), "The Costs and Benefits of Privatization An Incomplete Contracts Approach," Journal of Law, Economics and Organization, 12: 1-24.

[42] Shleifer, Andrei and Vishny, Robert (1993), "Corruption," Quarterly Journal of Economics 108: 599-617.

[43] Stasavage, David (2002), "Credible Commitment in Early Modern 
Europe: North and Weingast Revisited," The Journal of Law, Economics and Organization 18: 155-186.

[44] Stiglitz, Joseph (1974), "Incentives and Risk Sharing in Sharecropping," Review of Economic Studies 41: 219-255.

[45] Swart, Koenraad W. (1980), Sale of Office in the Seventeenth Century (Hes Publishers, Uthrect).

[46] Szostak, Rick (1991), The Role of Transportation in the Industrial Revolution - A Comparison of England and France (McGill-Queen's University Press, Montreal and Kingston).

[47] Toma Eugena F. and Toma Mark (1992), "Tax Collection with Agency Costs: Private Contracting or Government Bureaucrats," Economica, 59: 107-120.

[48] Velde, Francois R. and Weir, David R. (1992), "The Financial Market and Government Debt Policy in France, 1746-1793," Journal of Economic History 52: 1-39.

[49] Vierhaus Rudolf (1999), "The Preussian Bureaucracy Reconsidered," in The Eighteenth Century State in Britain and Germany, Brewer, John and Eckhart, Hellmut (eds.), (Oxford University Press, Oxford).

[50] Weber Max (1968), Economy and Society (Bedminster Press, New York, NY).

[51] Weir, David R. (1989), "Tontines, Public Finance and Revolution in France and England, 1688-1789," Journal of Economic History 49: $95-124$.

[52] White, Eugene N. (1995), "The French Revolution and the Politics of Government Finance, 1770-1815," Journal of Economic History 55: $227-255$. 
[53] White, Eugene N. (2004), "From Privatized to GovernmentAdministered Tax Collection: Tax Farming in Eighteenth-Century France," Economic History Review 57: 636-663.

[54] Zeldin, Theodore (1973), France, 1848-1945 (Clarendon Press, Oxford). 


\title{
CESifo Working Paper Series
}

\author{
(for full list see www.cesifo.de)
}

1397 Marko Köthenbürger, Panu Poutvaara and Paola Profeta, Why are More Redistributive Social Security Systems Smaller? A Median Voter Approach, February 2005

1398 Gabrielle Demange, Free Choice of Unfunded Systems: A First Assessment, February 2005

1399 Carlos Fonseca Marinheiro, Sustainability of Portuguese Fiscal Policy in Historical Perspective, February 2005

1400 Roel M. W. J. Beetsma and Koen Vermeylen, The Effect of Monetary Unification on Public Debt and its Real Return, February 2005

1401 Frank Asche, Petter Osmundsen and Maria Sandsmark, Is It All Oil?, February 2005

1402 Giacomo Corneo, Media Capture in a Democracy: The Role of Wealth Concentration, February 2005

1403 A. Lans Bovenberg and Thijs Knaap, Ageing, Funded Pensions and the Dutch Economy, February 2005

1404 Thiess Büttner, The Incentive Effect of Fiscal Equalization Transfers on Tax Policy, February 2005

1405 Luisa Fuster, Ayşe İmrohoroğlu and Selahattin İmrohoroğlu, Personal Security Accounts and Mandatory Annuitization in a Dynastic Framework, February 2005

1406 Peter Claeys, Policy Mix and Debt Sustainability: Evidence from Fiscal Policy Rules, February 2005

1407 James M. Malcomson, Supplier Discretion over Provision: Theory and an Application to Medical Care, February 2005

1408 Thorvaldur Gylfason, Interview with Assar Lindbeck, February 2005

1409 Christian Gollier, Some Aspects of the Economics of Catastrophe Risk Insurance, February 2005

1410 Gebhard Kirchgässner, The Weak Rationality Principle in Economics, February 2005

1411 Carlos José Fonseca Marinheiro, Has the Stability and Growth Pact Stabilised? Evidence from a Panel of 12 European Countries and Some Implications for the Reform of the Pact, February 2005

1412 Petter Osmundsen, Frank Asche, Bård Misund and Klaus Mohn, Valuation of International Oil Companies -The RoACE Era, February 2005 
1413 Gil S. Epstein and Shmuel Nitzan, Lobbying and Compromise, February 2005

1414 Marcel F. M. Canoy, Jan C. van Ours and Frederick van der Ploeg, The Economics of Books, February 2005

1415 Eric A. Hanushek and Ludger Wößmann, Does Educational Tracking Affect Performance and Inequality? Differences-in-Differences Evidence across Countries, February 2005

1416 George Kapetanios and M. Hashem Pesaran, Alternative Approaches to Estimation and Inference in Large Multifactor Panels: Small Sample Results with an Application to Modelling of Asset Returns, February 2005

1417 Samuel Mühlemann, Jürg Schweri, Rainer Winkelmann and Stefan C. Wolter, A Structural Model of Demand for Apprentices. February 2005

1418 Giorgio Brunello and Lorenzo Rocco, Educational Standards in Private and Public Schools, February 2005

1419 Alex Bryson, Lorenzo Cappellari and Claudio Lucifora, Why so Unhappy? The Effects of Unionisation on Job Satisfaction, March 2005

1420 Annalisa Luporini, Relative Performance Evaluation in a Multi-Plant Firm, March 2005

1421 Giorgio Bellettini and Carlotta Berti Ceroni, When the Union Hurts the Workers: A Positive Analysis of Immigration Policy, March 2005

1422 Pieter Gautier, Michael Svarer and Coen Teulings, Marriage and the City, March 2005

1423 Ingrid Ott and Stephen J. Turnovsky, Excludable and Non-Excludable Public Inputs: Consequences for Economic Growth, March 2005

1424 Frederick van der Ploeg, Back to Keynes?, March 2005

1425 Stephane Dees, Filippo di Mauro, M. Hashem Pesaran and L. Vanessa Smith, Exploring the International Linkages of the Euro Area: a Global VAR Analysis, March 2005

1426 Hans Pitlik, Friedrich Schneider and Harald Strotmann, Legislative Malapportionment and the Politicization of Germany's Intergovernmental Transfer System, March 2005

1427 Konstantinos Angelopoulos and Apostolis Philippopoulos, The Role of Government in Anti-Social Redistributive Activities, March 2005

1428 Ansgar Belke and Daniel Gros, Asymmetries in the Trans-Atlantic Monetary Policy Relationship: Does the ECB follow the Fed?, March 2005

1429 Sören Blomquist and Luca Micheletto, Optimal Redistributive Taxation when Government's and Agents' Preferences Differ, March 2005 
1430 Olof Åslund and Peter Fredriksson, Ethnic Enclaves and Welfare Cultures - QuasiExperimental Evidence, March 2005

1431 Paul De Grauwe, Roberto Dieci and Marianna Grimaldi, Fundamental and NonFundamental Equilibria in the Foreign Exchange Market. A Behavioural Finance Framework, March 2005

1432 Peter Egger, Stefan Gruber, Mario Larch and Michael Pfaffermayr, Knowledge-Capital Meets New Economic Geography, March 2005

1433 George Economides and Apostolis Philippopoulos, Should Green Governments Give Priority to Environmental Policies over Growth-Enhancing Policies?, March 2005

1434 George W. Evans and Seppo Honkapohja, An Interview with Thomas J. Sargent, March 2005

1435 Helge Berger and Volker Nitsch, Zooming Out: The Trade Effect of the Euro in Historical Perspective, March 2005

1436 Marc-Andreas Muendler, Rational Information Choice in Financial Market Equilibrium, March 2005

1437 Martin Kolmar and Volker Meier, Intra-Generational Externalities and InterGenerational Transfers, March 2005

1438 M. Hashem Pesaran and Takashi Yamagata, Testing Slope Homogeneity in Large Panels, March 2005

1439 Gjermund Nese and Odd Rune Straume, Industry Concentration and Strategic Trade Policy in Successive Oligopoly, April 2005

1440 Tomer Blumkin and Efraim Sadka, A Case for Taxing Education, April 2005

1441 John Whalley, Globalization and Values, April 2005

1442 Denise L. Mauzerall, Babar Sultan, Namsoug Kim and David F. Bradford, Charging $\mathrm{NO}_{x}$ Emitters for Health Damages: An Exploratory Analysis, April 2005

1443 Britta Hamburg, Mathias Hoffmann and Joachim Keller, Consumption, Wealth and Business Cycles in Germany, April 2005

1444 Kohei Daido and Hideshi Itoh, The Pygmalion Effect: An Agency Model with Reference Dependent Preferences, April 2005

1445 John Whalley, Rationality, Irrationality and Economic Cognition, April 2005

1446 Henning Bohn, The Sustainability of Fiscal Policy in the United States, April 2005

1447 Torben M. Andersen, Is there a Role for an Active Fiscal Stabilization Policy? April 2005 
1448 Hans Gersbach and Hans Haller, Bargaining Power and Equilibrium Consumption, April 2005

1449 Jerome L. Stein, The Transition Economies: A NATREX Evaluation of Research, April 2005

1450 Raymond Riezman, John Whalley and Shunming Zhang, Metrics Capturing the Degree to which Individual Economies are Globalized, April 2005

1451 Romain Ranciere, Aaron Tornell and Frank Westermann, Systemic Crises and Growth, April 2005

1452 Plutarchos Sakellaris and Focco W. Vijselaar, Capital Quality Improvement and the Sources of Growth in the Euro Area, April 2005

1453 Kevin Milligan and Michael Smart, Regional Grants as Pork Barrel Politics, April 2005

1454 Panu Poutvaara and Andreas Wagener, To Draft or not to Draft? Efficiency, Generational Incidence, and Political Economy of Military Conscription, April 2005

1455 Maurice Kugler and Hillel Rapoport, Skilled Emigration, Business Networks and Foreign Direct Investment, April 2005

1456 Yin-Wong Cheung and Eiji Fujii, Cross-Country Relative Price Volatility: Effects of Market Structure, April 2005

1457 Margarita Katsimi and Thomas Moutos, Inequality and Relative Reliance on Tariffs: Theory and Evidence, April 2005

1458 Monika Bütler, Olivia Huguenin and Federica Teppa, Why Forcing People to Save for Retirement may Backfire, April 2005

1459 Jos Jansen, The Effects of Disclosure Regulation of an Innovative Firm, April 2005

1460 Helge Bennmarker, Kenneth Carling and Bertil Holmlund, Do Benefit Hikes Damage Job Finding? Evidence from Swedish Unemployment Insurance Reforms, May 2005

1461 Steffen Huck, Kai A. Konrad and Wieland Müller, Merger without Cost Advantages, May 2005

1462 Louis Eeckhoudt and Harris Schlesinger, Putting Risk in its Proper Place, May 2005

1463 Hui Huang, John Whalley and Shunming Zhang, Trade Liberalization in a Joint Spatial Inter-Temporal Trade Model, May 2005

1464 Mikael Priks, Optimal Rent Extraction in Pre-Industrial England and France - Default Risk and Monitoring Costs, May 2005 